ИЗВЕСТИЯ АКАДЕМИИ НАУК ЭСТОНСКОП ССР. ТОМ 27 ХИМИЯ. 1978, № 3

\title{
О НЕКОТОРЫХ ХАРАКТЕРНЫХ ЧЕРТАХ ПИРИТОВ ПО ДАННЫМ СПЕКТРАЛЬНОГО АНАЛИЗА И ИНФРАКРАСНОЙ СПЕКТРОСКОПИИ
}

H. PALMRE, Helvi HODREJARV. PORIIDI MONINGAIST ISEARASUSTEST SPEKTRAALANALOUSI JA INFRAPUNASE SPEKTROSKOOPIA ANDMEIL

H. PALMRE, Helvi HODREJARV. SPECIFIC CHARACTERISTICS OF PYRITES ON THE BASIS OF SPECTRUM ANALYSIS AND INFRARED SPECTROSCOPY

Изучение встречаемости и формы нахождения элементов-примесей в минералах позволяет судить не только о генезисе последних, но и о степени однородности отдельных минералов. Зачастую минералы, представляющиеся микро- и макроскопически однородными, после их химического и спектрального анализа, а также после исследования методом инфракрасной спектроскопии [1,2], оказываются неоднородными по своему составу.

Нами исследовались примеси в кристаллах пирита из свинцово-цинкового рудопроявления центральной части Эстонии (обнажения реки Навести) и из нижнесилурийских отложений (обнажения Саастна в западной Эстонии). В обнажениях Навести пирит встречается в доломитах адавереского горизонта совместно с галенитом, сфалеритом, халькопиритом и др. минералами, а в обнажениях Саастна кристаллы пирита находятся в мергелях, мергелистых известняках адавереского горизонта и являются диагенетическими. Образцы сульфидных минералов отбирались по профилям обнажений с учетом геологического положения и характера вмещающих пород. Собранные минералы промывались разбавленной $\mathrm{HCl}$ для удаления посторонних примесей с поверхности кристаллов. Мономинеральная фракция (более 300 проб) отбиралась под бинокулярным микроскопом. Определение элементов-примесей проводилось по методике, разработанной Х. Хедреярв [3].

Сравнивая встречаемость и распространение элементов-примесей в диагенетических пиритах (обнажения Саастна) и в кристаллах пирита гидротермального происхождения (обнажения Навести), можно констатировать более низкую концентрацию свинца и, по-видимому, также цинка в диагенетических пиритах (табл. 1).

8 образцов пирита были подвергнуты также инфракрасной спектроскопии. Образцы изготовлялись путем прессования исследуемых минералов с бромидовым калием. Запись ИК-спектров поглощения проводилась на двулучевом ИK-спектрофотометре UR-10M (фирмы К. Цейсса 


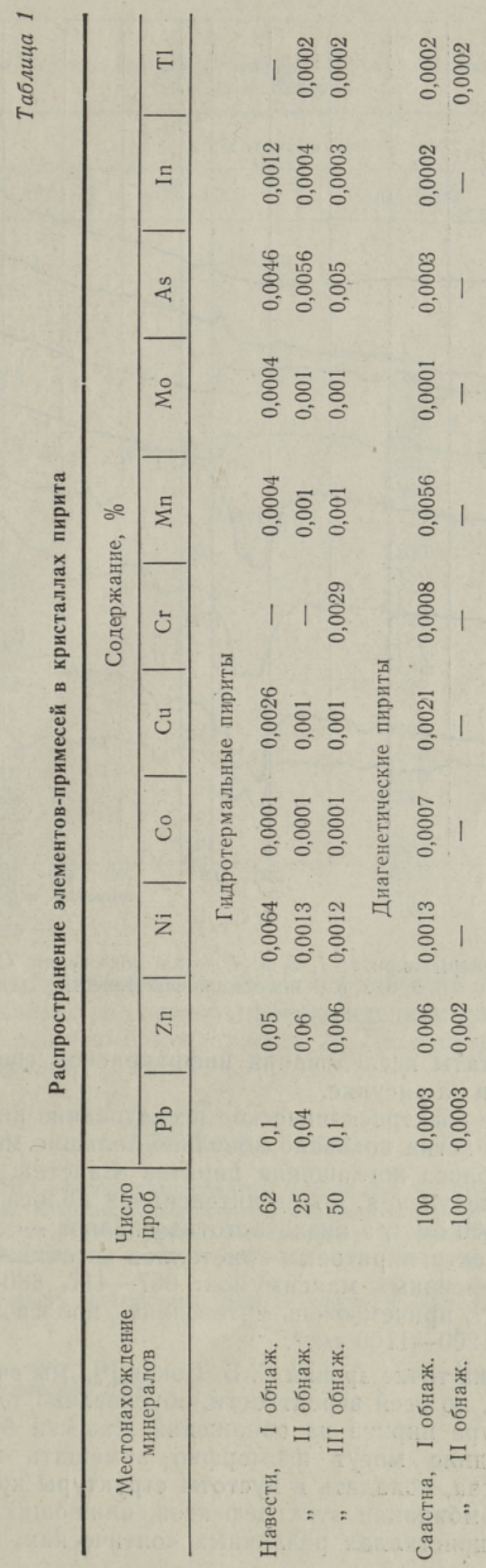




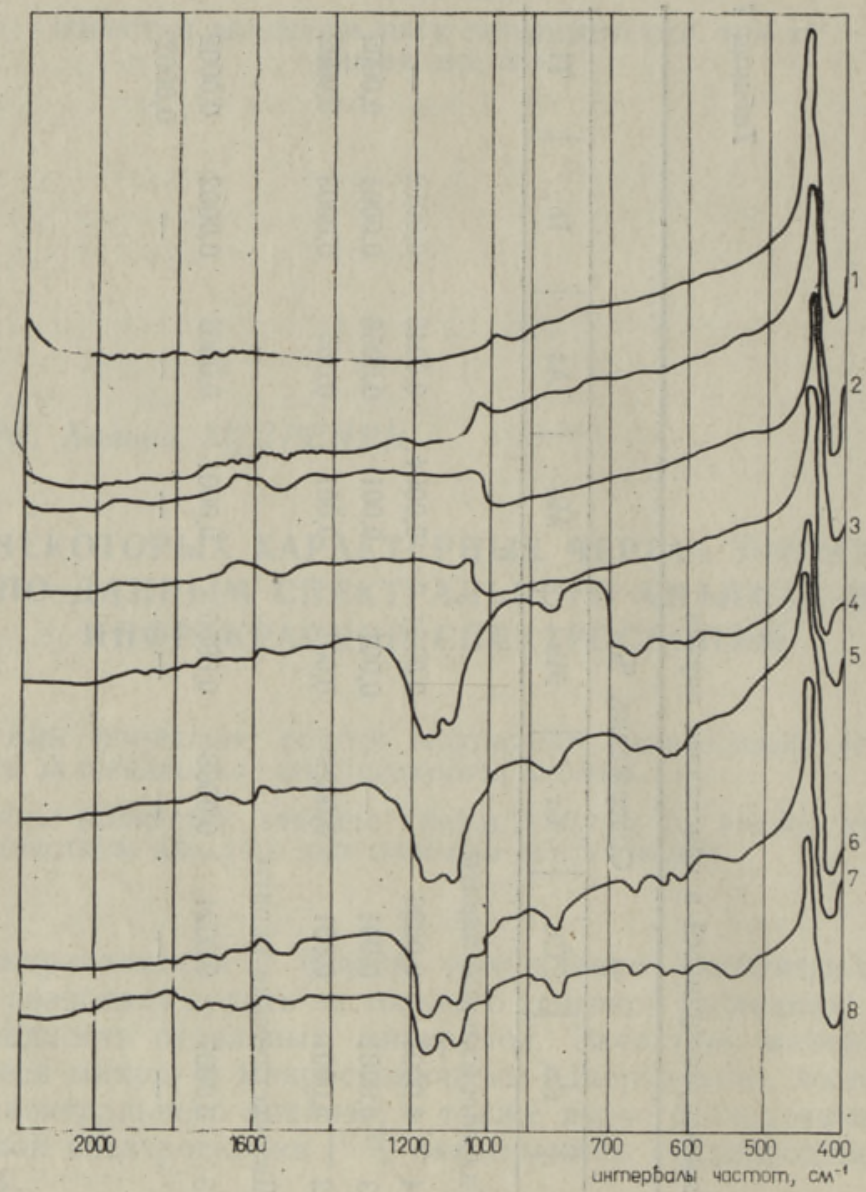

ИК-спектры пирита: $1,2,3,4$ - из обнажений Саастна; $5,6,7,8$ - из обнажений Навести.

«Иена»). Результаты исследования инфракрасной спектроскопией приведены в табл. 2 и на рисунке.

Инфракрасное спектроскопическое исследование пиритов из обнажений Навести и Саастна показало довольно большие между ними различия. Основная полоса поглощения пиритов Саастна лежит в области $420-415 \mathrm{~cm}^{-1}$, следующая, более интенсивная полоса поглощения - в области $1580-1060 \mathrm{CM}^{-1}$, а низкочастотная полоса - в пределах 2900 $2100 \mathrm{~cm}^{-1}$. ИК-спектр пиритовых кристаллов из обнажения Навести содержит ряд интеноивных максимумов: $667-417,880-830,1490-1100$ и 2940-2860 $\mathrm{cm}^{-1}$, причем очень интенсивная полоса поглощения находится в области $1200-1100 \mathrm{~cm}^{-1}$.

Основываясь на точке зрения Г. Б. Бокия [4], мы считаем, что различие ИК-спектров, по всей вероятности, обусловлено тем, что в кристаллической структуре пирита из обнажений Навести больше элементовпримесей. Последние могут изоморфно замещать некоторые атомы основного вещества, попадать в пустоты структуры кристалла и давать всевозможные комбинации этих дефектов, влияющих, в свою очередь, на появление в кристаллах различных «оптических центров». Можно 
таблица 2

Инфракрасные спектры поглощения пиритов из обнажений Саастна и Навести

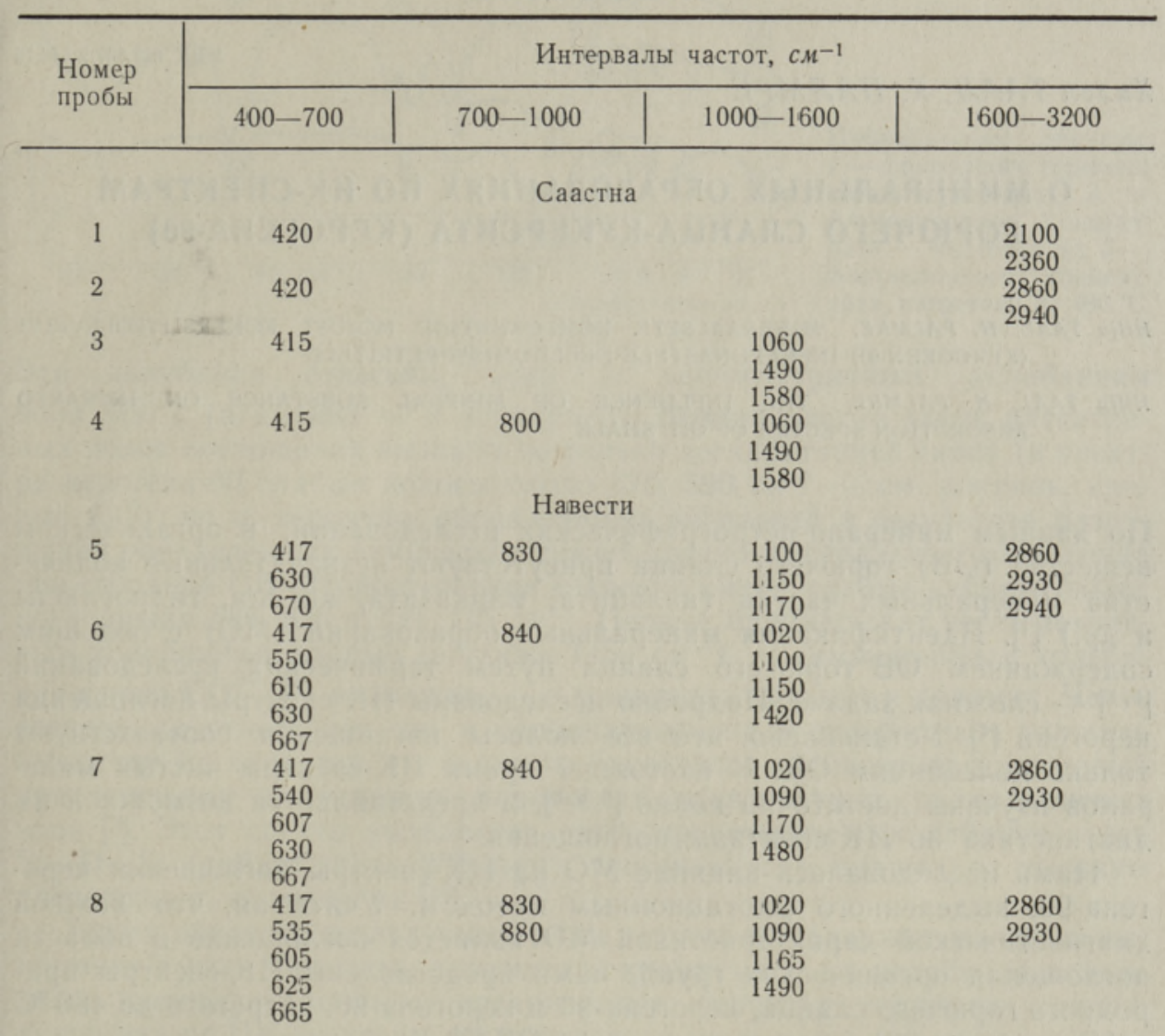

также полагать, что различия в спектрах поглощения образцов из Саастна и Навести связаны с различным происхождением пиритов.

Выражаем искреннюю благодарность Л. Лахе за выполнение анализов ИК-спектроскопии.

\section{ЛИТЕРАТ У РА}

1. Болдыр е в А. Н. Инфракрасные спектры минералов. М., 1976.

2. Плюсн ин а И. И. Инфракрасные спектры минералов. М., 1977.

3. Хедреярв X. Разработка химико-спектральных методов определения редких и рассеянных элементов в эстонских галенитах. Автореф. канд. дис. Таллин, 1967.

4. Боки й Г. Б. Границы применения понятия «изоморфизм». Изоморфизм в минералах. М., 1975. 